Article

\title{
Development of an Aptamer Based Luminescent Optical Fiber Sensor for the Continuous Monitoring of $\mathrm{Hg}^{2+}$ in Aqueous Media
}

\author{
Nerea De Acha ${ }^{1, *}$, César Elosúa ${ }^{1,2}$ and Francisco J. Arregui 1,2 (D) \\ 1 Department of Electrical, Electronic and Communications Engineering, Public University of Navarra, \\ Ed. Los Tejos, Campus Arrosadía s/n, E-31006 Pamplona, Navarra, Spain \\ 2 Institute of Smart Cities, Public University of Navarra, Ed. Jerónimo de Ayanz, Campus Arrosadía s/n, \\ E-31006 Pamplona, Navarra, Spain \\ * Correspondence: nerea.deacha@unavarra.es; Tel.: +34-948-166-044
}

Received: 22 March 2020; Accepted: 20 April 2020; Published: 22 April 2020

check for updates

\begin{abstract}
A fluorescent optical fiber sensor for the detection of mercury $\left(\mathrm{Hg}^{2+}\right)$ ions in aqueous solutions is presented in this work. The sensor was based on a fluorophore-labeled thymine (T)-rich oligodeoxyribonucleotide (ON) sequence that was directly immobilized onto the tip of a tapered optical fiber. In the presence of mercury ions, the formation of $\mathrm{T}-\mathrm{Hg}^{2+}-\mathrm{T}$ mismatches quenches the fluorescence emission by the labeled fluorophore, which enables the measurement of $\mathrm{Hg}^{2+}$ ions in aqueous solutions. Thus, in contrast to commonly designed sensors, neither a fluorescence quencher nor a complementary $\mathrm{ON}$ sequence is required. The sensor presented a response time of 24.8 seconds toward $5 \times 10^{-12} \mathrm{M} \mathrm{Hg}^{2+}$. It also showed both good reversibility (higher than the 95.8\%) and selectivity: the $\mathrm{I}_{0} / \mathrm{I}$ variation was 10 times higher for $\mathrm{Hg}^{2+}$ ions than for $\mathrm{Mn}^{2+}$ ions. Other contaminants examined $\left(\mathrm{Co}^{2+}, \mathrm{Ag}^{+}, \mathrm{Cd}^{2+}, \mathrm{Ni}^{2+}, \mathrm{Ca}^{2+}, \mathrm{Pb}^{2+}, \mathrm{Mn}^{2+}, \mathrm{Zn}^{2+}, \mathrm{Fe}^{3+}\right.$, and $\left.\mathrm{Cu}^{2+}\right)$ presented an even lower interference. The limit of detection of the sensor was $4.73 \times 10^{-13} \mathrm{M} \mathrm{Hg}^{2+}$ in buffer solution and $9.03 \times 10^{-13} \mathrm{M} \mathrm{Hg}^{2+}$ in ultrapure water, and was also able to detect $5 \times 10^{-12} \mathrm{M} \mathrm{Hg}^{2+}$ in tap water.
\end{abstract}

Keywords: optical fiber biosensor; luminescent biosensor; fluorophore-labelled aptamer; mercury detection

\section{Introduction}

Assuring a good quality of water is essential in order to guarantee the health of the population and the quality of the environment [1]. Thus, public institutions are increasingly concerned about monitoring the presence of different water pollutants such as plastics [2], pesticides [3], or metal ions [4] in aqueous media, even at trace levels. Among the different metal ions, mercury $\left(\mathrm{Hg}^{2+}\right)$ is known to be one of the most toxic species of aqueous media [5]. Apart from being related to carcinogenic processes and neurodegenerative illnesses [6], $\mathrm{Hg}^{2+}$ ions present an accumulative effect in the human body [7] and are non-degradable [8], so their monitoring is crucial in order to assure a good quality of water. In fact, the European Union (EU) has established the maximum allowable mercury concentration in surface water as $3.49 \times 10^{-10} \mathrm{M}$ [9]. As a consequence, the detection of this water contaminant has attracted the interest of scientists during the last few years, leading to the development of a wide variety of $\mathrm{Hg}^{2+}$-sensitive devices [10-12].

It is well known that a key parameter of sensors is their selectivity [13], thus, currently, aptamers have been widely utilized as these single-stranded oligonucleotides have the capability of binding to certain molecules with high affinity and specificity, so they provide a high selectivity [14]. In particular, 
due to the high reactivity that thymine (T) presents for $\mathrm{Hg}^{2+}$ ions [15], T-rich oligodeoxyribonucleotide $(\mathrm{ON})$ sequences have been used for $\mathrm{Hg}^{2+}$ sensing purposes [16], presenting low cross-sensitivity values for other metal ions. For instance, $\mathrm{Li}$ et al. [17] reported a device that showed negligible interference from $\mathrm{K}^{+}, \mathrm{Ag}^{+}, \mathrm{Ca}^{2+}, \mathrm{Cd}^{2+}, \mathrm{Co}^{2+}, \mathrm{Cu}^{2+}, \mathrm{Fe}^{3+}, \mathrm{Ni}^{2+}$, and $\mathrm{Pb}^{2+}$ : even when their concentrations were four-fold higher than that of $\mathrm{Hg}^{2+}\left(200 \mathrm{nM}\right.$ of other metal ions against $50 \mathrm{nM}$ of $\mathrm{Hg}^{2+}$ ), the sensor response barely changed. Further examples of aptamer-based sensors that exhibit high selectivity were analyzed in detail in [18]. Furthermore, $\mathrm{T}-\mathrm{Hg}^{2+}-\mathrm{T}$ has the capability of absorbing the electrons emitted by a fluorophore labelled to one of the termini of the ON sequences [19], causing a quenching of the emitted intensity [20]. This fact entails several advantages over the $\mathrm{Hg}^{2+}$ sensors developed to date: first, there is no need to utilize any complementary $\mathrm{ON}$ sequence (thus, the $\mathrm{Hg}^{2+}$ ion concentration of the sample is not altered), which usually happens with this kind of sensor [21]; and second, no quencher has to be labelled to the opposite termini of the same ON [22], which enables the sensitive ON sequence to be directly immobilized onto a substrate.

Among the different substrates that can be employed for the fabrication of these sensors, optical fiber can be considered as one of the most suitable. As it is made of silica, the chemical robustness and lack of oxidation of this material enables it to be placed in aqueous media for long periods of time [23]. Furthermore, optical fiber sensors do not require referenced measurements like pH-meters or ion-meters [24].

Another advantage that optical fiber offers is that silica surfaces can be easily modified in order to allow the deposition of different materials such as polymers [25], polyelectrolytes [26], or even biochemical species [27]. Furthermore, the properties of the deposited materials can be tailored in a nanometric scale [28], which enables the fabrication of custom-made sensors. Moreover, optical fiber shows interesting features for the development of luminescence-based sensors: it permits a robust and simple experimental set-up where the light source, the sensor, and spectrometer are directly connected, in which the excitation and the luminescence signals are transmitted through the same fiber [29]. Additionally, the optical fiber tip can be shaped to couple as much light as possible [30].

As has been previously explained, monitoring $\mathrm{Hg}^{2+}$ ions at trace levels is relevant. In addition, T-rich ON sequences show interesting features for the detection of these ions: they present high affinity toward them, and, furthermore, the $\mathrm{T}-\mathrm{Hg}^{2+}-\mathrm{T}$ mismatches can quench the fluorescence emissions. Thus, in this work, a fluorophore labeled ON sequence was immobilized onto the tapered end of an optical fiber. The behavior of the sensor in terms of sensitivity, reversibility, and cross-sensitivity was analyzed in a phosphate buffered solution (PBS). To check out the further applicability of the sensor, $\mathrm{Hg}^{2+}$ ions detection was also studied in ultrapure water and tap water.

\section{Materials and Methods}

\subsection{Chemicals and Reagents for the Fabrication of the Sensor}

Due to the high affinity of thymine (T) rich ON sequences for $\mathrm{Hg}^{2+}$ ions [15], in this work the HPLC-grade oligodeoxyribonucleotide sequence $5^{\prime}-\mathrm{NH}_{2}-\left(\mathrm{CH}_{2}\right)_{6}-\mathrm{TTCTTTCTTCGCGTTGTTTG}$ TT-Atto390- $3^{\prime}$ was used as the $\mathrm{Hg}^{2+}$-sensitive material (purchased from Metabion (Planegg, Germany)). For its storage, a $50 \mu \mathrm{M}$ probe stock solution was prepared in a $10 \mathrm{mM}$ phosphate buffered solution (PBS) (acquired from Merck (Darmstadt, Germany)) at $\mathrm{pH} 7.4$, which was kept frozen at $-22^{\circ} \mathrm{C}$ in the absence of light.

The utilization of this sequence involves a key advantage over other $\mathrm{ON}$ sequence-based $\mathrm{Hg}^{2+}$ sensors, as the $\mathrm{T}-\mathrm{Hg}^{2+}-\mathrm{T}$ mismatches absorb the electrons emitted by the labelled atto390 (consequently quenching the fluorescent emission), there is no need to use either a quencher [31] or a complementary sequence [32]. This also allows the sequence to become directly attached onto the optical fiber, as it is explained hereafter.

The cleaved end of a fiber pigtail was modified to increase the interface area and therefore the coupled luminescent emission. To achieve this, a taper was shaped on the tip of the optical 
fiber with hydrofluoric acid (HF) (48\% purity); the surrounding cladding was removed with ethanol (99.8\% purity). Both were bought from Panreac (Barcelona, Spain).

Thereafter, the cleaning and activation processes of the optical fiber surface were performed using a piranha solution $\left(\mathrm{H}_{2} \mathrm{SO}_{4} / \mathrm{H}_{2} \mathrm{O}_{2}, 3: 1(\mathrm{v} / \mathrm{v})\right.$, acquired at Sigma Aldrich (Darmstadt, Germany) and Panreac (Barcelona, Spain), respectively).

For the immobilization of the $\mathrm{Hg}^{2+}$-sensitive $\mathrm{ON}$ sequence on the surface of the optical fiber, (3-aminopropyl)trimethoxysilane (97\%) (APTMS), methanol (99.8\% purity), and glutaraldehyde (GA) (25\% aqueous solution) were utilized. These were purchased from Sigma Aldrich (Darmstadt, Germany) and used as received.

\subsection{Taper Fabrication}

In order to couple as much luminescence emission as possible from the fluorophore-labeled ON sequence to the optical fiber, it was immobilized onto the tapered end of a $1000 \mu \mathrm{m}$-core plastic cladding silica fiber $[33,34]$. The length of the taper was $3 \mathrm{~mm}$, and it was fabricated by the subsequent immersion and withdrawal of the tip of the optical fiber in and out of a $48 \%(\mathrm{v} / \mathrm{v})$ hydrofluoric acid solution at constant speeds of $100 \mathrm{~mm} / \mathrm{min}$ and $2 \mathrm{~mm} / \mathrm{min}$, respectively. This procedure was repeated 40 times and afterward, the cladding of the fiber was removed with a flame and the resulting taper was cleaned with ethanol.

\subsection{Immobilization of the ON Sequence onto the Optical Fiber}

The immobilization procedure of the $\mathrm{ON}$ sequence onto the tapered end of the fiber, which is shown in Figure 1, consisted of the following steps [35]: first, the cleaning and $\mathrm{OH}^{-}$group activation processes of the fiber surface were carried out by immersing for $10 \mathrm{~min}$ in the piranha solution, followed by a thorough wash with ultrapure water. For the amination of the optical fiber, it was kept for $16 \mathrm{~h}$ in a $2 \%(\mathrm{v} / \mathrm{v})$ APTMS solution in methanol, then washed with methanol, and dried for an hour at $110{ }^{\circ} \mathrm{C}$ afterwards. Subsequently, the aminated fiber was dipped for an hour in a GA solution $(10 \%(\mathrm{v} / \mathrm{v})$ in PBS ( $\mathrm{pH} 8.5)$ ) at $21^{\circ} \mathrm{C}$ and washed with ultrapure water. Finally, the $\mathrm{ON}$ sequence was adsorbed onto the fiber by immersing it for 2 hours in a $250 \mathrm{nM}$ aptamer solution in $10 \mathrm{mM}$ PBS (pH 7.4) mixture and washed with $10 \mathrm{mM}$ PBS (pH 7.4). All sensors were stored at $4{ }^{\circ} \mathrm{C}$ in the absence of light and were fabricated following this procedure.

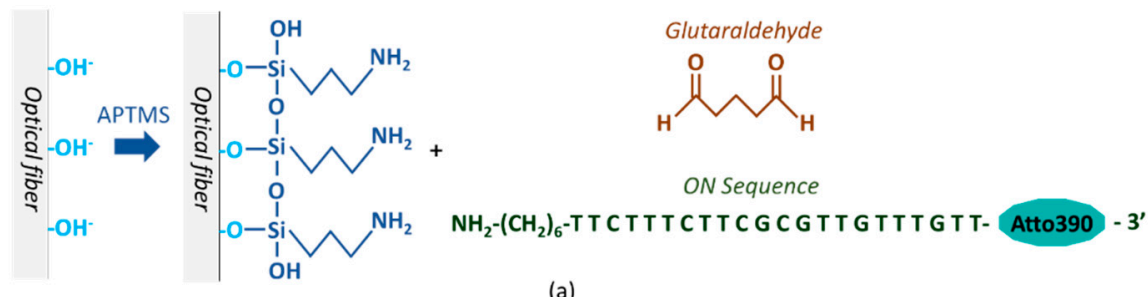

(a)

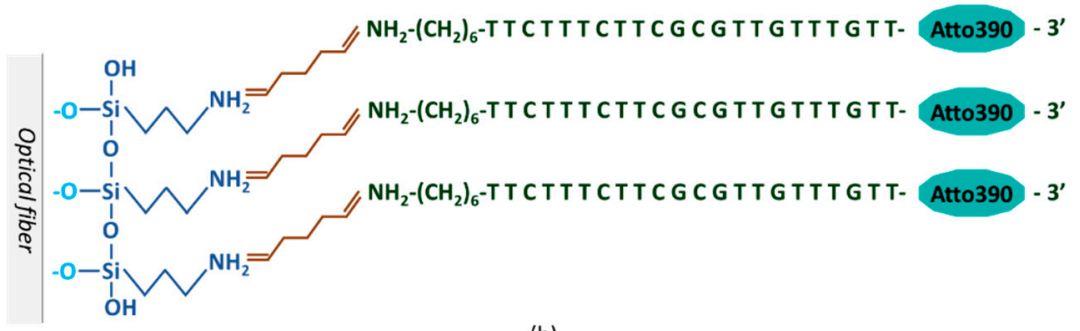

(b)

Figure 1. (a) Immobilization process of the $\mathrm{ON}$ sequence onto the surface of the optical fiber: first, the $\mathrm{OH}^{-}$groups were activated with piranha solution, then the surface was silanized with APTMS and finally, the ON sequence was cross-linked utilizing glutaraldehyde. (b) Schematic of the sensing structure. 


\subsection{Preparation of the Samples for $\mathrm{Hg}^{2+}$ Analysis}

Since the first part of this study consisted of the detection of $\mathrm{Hg}^{2+}$ ions in $10 \mathrm{mM} \mathrm{PBS} \mathrm{(pH} \mathrm{7.4)} \mathrm{solution,}$ a $10^{-2} \mathrm{M} \mathrm{Hg}^{2+}$ stock solution in PBS was prepared. This solution was subsequently diluted to obtain $5 \times 10^{-12} \mathrm{M} \mathrm{Hg}^{2+}, 10^{-11} \mathrm{M} \mathrm{Hg}^{2+}, 5 \times 10^{-11} \mathrm{M} \mathrm{Hg}^{2+}, 10^{-10} \mathrm{M} \mathrm{Hg}^{2+}, 5 \times 10^{-10} \mathrm{M} \mathrm{Hg}^{2+}, 10^{-9} \mathrm{M} \mathrm{Hg}^{2+}$, and $5 \times 10^{-9} \mathrm{M} \mathrm{Hg}^{2+}$ solutions in PBS ( $\mathrm{pH}$ 7.4). The latter was the highest $\mathrm{Hg}^{2+}$ ion concentration analyzed because higher ones were not considered of interest, as the maximum $\mathrm{Hg}^{2+}$ concentration allowed by the EU in surface water is $3.49 \times 10^{-10} \mathrm{M}[9]$.

A similar procedure was carried out in order to achieve the different concentrations of $\mathrm{Hg}^{2+}$ ions in ultrapure water and in tap water. In order to regenerate the sensing film, a $0.5 \%(\mathrm{w} / \mathrm{w})$ sodium dodecyl sulfate (SDS) [36] (Sigma Aldrich (Darmstadt, Germany)) solution was prepared.

Finally, with the aim of analyzing the cross-sensitivity of the sensor toward other metal ions, $10^{-6} \mathrm{M}$ solutions of $\mathrm{Co}^{2+}, \mathrm{Ag}^{+}, \mathrm{Cd}^{2+}, \mathrm{Ni}^{2+}, \mathrm{Ca}^{2+}, \mathrm{Pb}^{2+}, \mathrm{Mn}^{2+}, \mathrm{Zn}^{2+}, \mathrm{Fe}^{3+}$, and $\mathrm{Cu}^{2+}$ in PBS (pH 7.4) were respectively obtained from standard solutions of $\mathrm{Co}\left(\mathrm{NO}_{3}\right)_{2}, \mathrm{AgNO}_{3}, \mathrm{Cd}\left(\mathrm{NO}_{3}\right)_{2}, \mathrm{Ni}\left(\mathrm{NO}_{3}\right)_{2}, \mathrm{Ca}\left(\mathrm{NO}_{3}\right)_{2}$, $\mathrm{Pb}\left(\mathrm{NO}_{3}\right)_{2}, \mathrm{Mn}\left(\mathrm{NO}_{3}\right)_{2}, \mathrm{Zn}\left(\mathrm{NO}_{3}\right)_{2}, \mathrm{Fe}\left(\mathrm{NO}_{3}\right)_{3}$ and $\mathrm{Cu}\left(\mathrm{NO}_{3}\right)_{2}$ in $0.5 \mathrm{~mol} / \mathrm{l}$ of nitric acid. All were purchased from Merck (Darmstadt, Germany).

\subsection{Sensing Mechanism}

T-rich ON sequences are well-known for their high affinity toward $\mathrm{Hg}^{2+}$ ions [15]: in particular, in the presence of this metal ion, $\mathrm{T}-\mathrm{Hg}^{2+}-\mathrm{T}$ mismatches are formed [37], causing the ON sequence to acquire a hairpin structure [38], as depicted in Figure 2. Furthermore, in the case of fluorophore-labeled ON sequences, there was an electron transfer from the excited fluorophore to the $\mathrm{T}-\mathrm{Hg}^{2+}-\mathrm{T}$ pairs [19], which was the cause of the decrease in the luminescent emission of the fluorophore [20]. This fact has been widely employed to develop luminescent $\mathrm{Hg}^{2+}$ ion sensors that use ON sequences [39].

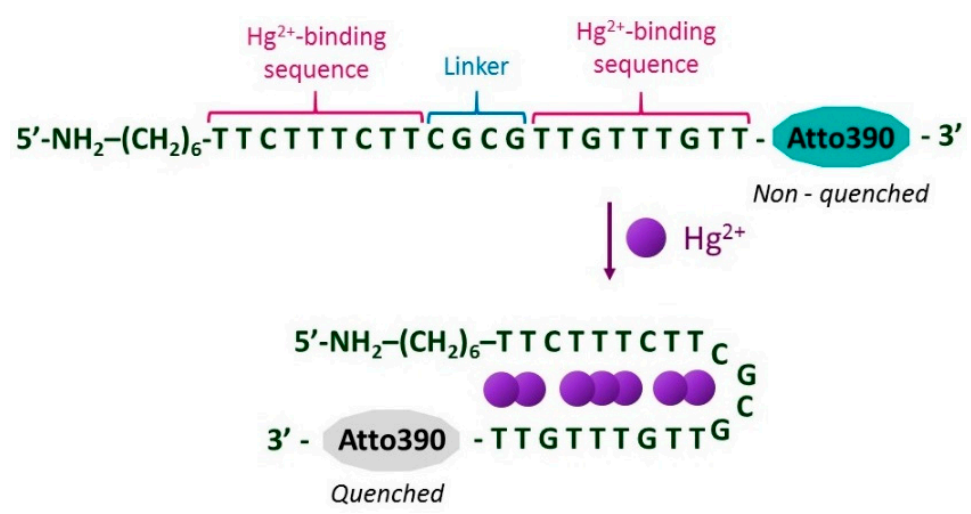

Figure 2. Schematic representation of the hairpin structure acquired by the $\mathrm{ON}$ sequence in the presence of $\mathrm{Hg}^{2+}$ ions due to the formation of $\mathrm{T}-\mathrm{Hg}^{2+}-\mathrm{T}$ mismatches, which also quenches the luminescence emission of the fluorophore Atto390.

As SDS is a chemical denaturant, it has been commonly used for the regeneration of this kind of sensor [35]: the hydrocarbon tail of the surfactant binds to the ON sequence [40]. This provokes the dissociation of the $\mathrm{T}-\mathrm{Hg}^{2+}-\mathrm{T}$ mismatches and restores the sensor response; when these structures are disjointed, there is no absorption of the luminescent emission, so it recovers its original intensity.

\subsection{Characterization of the Sensors}

In order to analyze the response of the sensor to distinct $\mathrm{Hg}^{2+}$ ion concentrations in aqueous solutions, it was first exposed to PBS ( $\mathrm{pH}$ 7.4) mixtures with different $\mathrm{Hg}^{2+}$ concentrations. The characterization was performed as follows: 
- First, the sensor was exposed to the continuous illumination of the LED for at least 90 minutes to estimate the mathematical characterization of the photobleaching suffered by the fluorophore labelled to the ON sequence [41]. During this test, the sensor was in a PBS (pH 7.4) solution.

- Hereafter, it was exposed for five minutes to a PBS ( $\mathrm{pH} 7.4$ ) solution with a certain $\mathrm{Hg}^{2+}$ concentration and then regenerated by dipping it in a $0.5 \%(\mathrm{w} / \mathrm{w}) \mathrm{SDS}$ solution.

- Afterward, the sensor was introduced again into a PBS (pH 7.4) solution for 20 minutes until the fluorescence became stabilized.

The behavior of the sensor toward $\mathrm{Hg}^{2+}$ (in terms of luminescent intensity and kinetics) was analyzed by repeating this procedure successively with different concentrations of $\mathrm{Hg}^{2+}$ ions in PBS ( $\mathrm{pH}$ 7.4) solutions. The detection of $\mathrm{Hg}^{2+}$ in ultrapure (or tap) water was carried out in a similar procedure, only replacing the PBS solution with ultrapure or tap water.

Regarding the luminescence measurements, in order to avoid any kind of fluctuation of the luminescent intensity due to undesired artifacts of the light source [41], all of the recorded spectra were normalized to the LED averaged intensity at $390 \mathrm{~nm}$.

The calibration curves of the sensors in each media were obtained by dividing the normalized luminescence intensity of each sensor in the absence of $\mathrm{Hg}^{2+}$ ions $\left(\mathrm{I}_{0}\right)$ by the normalized intensity of the sensor for the different $\mathrm{Hg}^{2+}$ concentrations (I) [42].

\section{Experimental Set-Up}

Due to the nature of the light signal and to have a robust experimental set-up, an optimized reflection architecture was employed (see Figure 3) [41]. The configuration was based on the utilization of a $600 \mu \mathrm{m}$-core bifurcated fiber (acquired at Ocean Insight (Ostfildern, Germany)): the sensor was connected to the common branch of this fiber (3), whereas the LSL Maya spectrometer (from Ocean Insight (Ostfildern, Germany)) and a LED centered at $365 \mathrm{~nm}$ (purchased from Pyroistech (Pamplona, Spain)) were connected to branches (1) and (2) of the bifurcated fiber, respectively. The interrogating signal from the source was coupled via branch (1) toward the sensor head where it excited the luminescent emission of the sensing material (modulated by the $\mathrm{Hg}^{2+}$ ion concentration); on the other hand, the sensor response was guided backward through branch (2) to the spectrometer. The luminescent emission of the Atto390 (centered at $460 \mathrm{~nm}$ ) required a high optical power that was also reflected in the sensor tip and could overlap the sensing signal. To reduce this effect, on one hand, the LED was connected through a $200 \mu \mathrm{m}$-core optical fiber to an adjustable low pass filter (LPF) from Ocean Optics, with its cut-off wavelength at $390 \mathrm{~nm}$, and then to branch (1); on the other hand, the stretched end of the sensor (described in Section 2.2) reduced the reflected interrogating signal. All the spectra were registered by the software OceanView 1.0 (Ocean Insight (Ostfildern, Germany)) using an integration time of $1500 \mathrm{~ms}$.

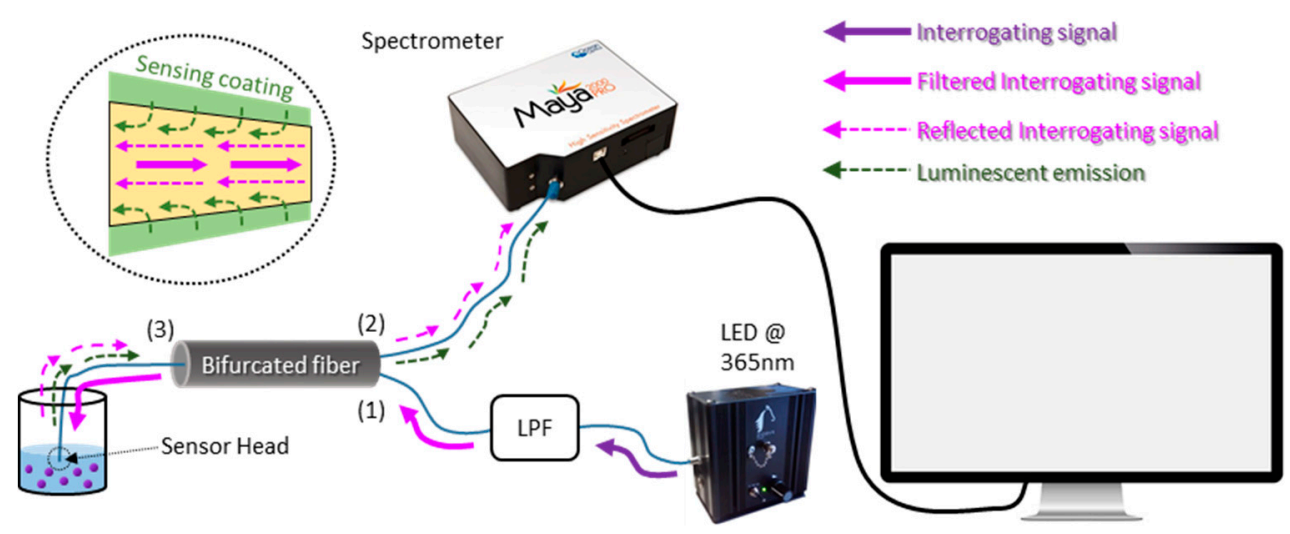

Figure 3. Experimental set-up utilized to characterize the sensor: the blue lines correspond to the optical fibers, while the black one represents the USB cable. (Inset) A scheme of the sensor tip. 


\section{Results and Discussion}

\subsection{Detection of $\mathrm{Hg}^{2+}$ Ions in Phosphate Buffered Solution (PBS, pH 7.4) Solutions}

The behavior of the sensor toward $\mathrm{Hg}^{2+}$ was first analyzed in $10 \mathrm{mM}$ PBS (pH 7.4) solutions. The $\mathrm{Hg}^{2+}$ concentration studied ranged three and a half orders of magnitude. To have a representative characterization along this span, the concentrations chosen were the limits of each decade and the middle point between them: $5 \times 10^{-12} \mathrm{M} \mathrm{Hg}^{2+}, 10^{-11} \mathrm{M} \mathrm{Hg}^{2+}, 5 \times 10^{-11} \mathrm{M} \mathrm{Hg}^{2+}, 10^{-10} \mathrm{M} \mathrm{Hg}^{2+}$, $5 \times 10^{-10} \mathrm{M} \mathrm{Hg}^{2+}, 10^{-9} \mathrm{M} \mathrm{Hg}^{2+}$, and $5 \times 10^{-9} \mathrm{M} \mathrm{Hg}^{2+}$. The sensor was regenerated with $0.5 \%(\mathrm{w} / \mathrm{w})$ SDS afterward and then dipped for 20 minutes into PBS solution with no metallic ions.

The dynamic variation of the normalized luminescence intensity for these concentrations is displayed in Figure 4: as can be observed, the emitted intensity immediately decreased in the presence of a $5 \times 10^{-12} \mathrm{M}$ (and higher) $\mathrm{Hg}^{2+}$ ion concentration and increased while the sensor was being regenerated with $0.5 \%(\mathrm{w} / \mathrm{w})$ SDS. Once the sensor was immersed again in PBS, the luminescence recovered between $95.8 \%$ and $99.17 \%$ of its original value. This kind of drift in the baseline is commonly reported in the bibliography and can be mathematically compensated $[43,44]$. In this specific case, these intensity variations during and after the immersion of the sensor in SDS might be explained by the effect of this compound on the ON sequence: first, SDS induced an unfolding of the sequence [45] and this conformational change led to an increase in the fluorescence intensity (Figure 4a). Second, due to the unfolding of the $\mathrm{ON}$ sequence, the bonds between $\mathrm{Hg}^{2+}$ and $\mathrm{T}$ groups were broken, thus, the recovery values between $95.8 \%$ and $99.17 \%$ implied that not all of the $\mathrm{T}-\mathrm{Hg}^{2+}-\mathrm{T}$ mismatches were fragmented.
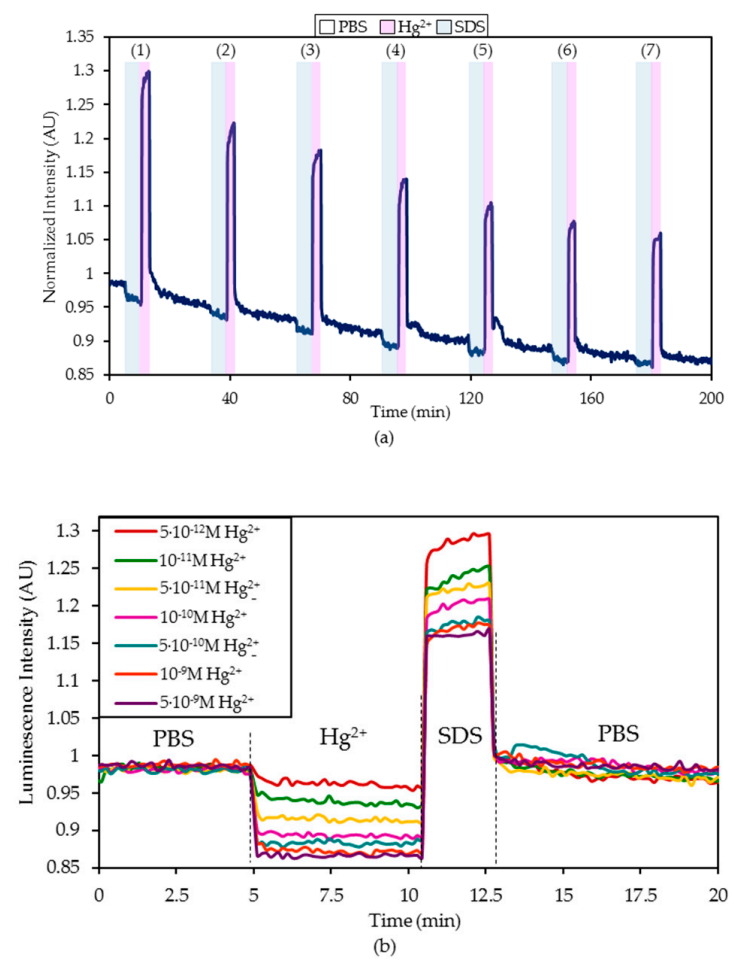

Figure 4. (a) Dynamic variation of the normalized luminescence intensity under 5 min exposure to different $\mathrm{Hg}^{2+}$ concentrations ((1) $5 \times 10^{-12} \mathrm{M}$, (2) $10^{-11} \mathrm{M}$, (3) $5 \times 10^{-11} \mathrm{M}$, (4) $10^{-10} \mathrm{M}$, (5) $5 \times 10^{-10} \mathrm{M}$, (6) $\left.10^{-9} \mathrm{M},(7) 5 \times 10^{-9} \mathrm{M}\right), 2 \mathrm{~min}$ regeneration with $0.5 \% \mathrm{w} / \mathrm{w}$ SDS and $20 \mathrm{~min}$ stabilization in phosphate buffered solution (PBS) ( $\mathrm{pH} 7.4$ ). (b) Detail of the intensity variation for each $\mathrm{Hg}^{2+}$ concentration in PBS buffer.

Looking to ensure that the $\mathrm{Hg}^{2+}$ ions were interacting with the $\mathrm{ON}$ sequence and there were no other interfering parameters, the refractive indices [35] and $\mathrm{pH}$ values [46] of the different $\mathrm{Hg}^{2+}$ 
solutions were checked. All of them presented similar refractive indices and $\mathrm{pH}$ values to the reference solution (PBS, pH 7.4), as can be observed in Supplementary Table S1.

Figure $4 \mathrm{~b}$ shows the zoomed response before, during, and after the exposure to the different $\mathrm{Hg}^{+2}$ concentrations to ease the comparison between them. All the signal variations were referenced to the intensity level of the first immersion into PBS. The response time for the sensor was faster as the $\mathrm{Hg}^{2+}$ concentration increased: for the slowest case measured with $5 \times 10^{-12} \mathrm{M} \mathrm{Hg}^{2+}$, it was 24.8 seconds.

The normalized luminescence peaks for each concentration are shown in Figure 5 and the calibration curve of the sensor is displayed in Figure 6. Considering these data, it can be estimated that the limit of detection (LOD) [47] was $4.73 \times 10^{-13} \mathrm{M} \mathrm{Hg}^{2+}$. Its dynamic range was from $5 \times 10^{-12} \mathrm{M}$ to $10^{-10} \mathrm{M} \mathrm{Hg}^{2+}$, and it was saturated with concentrations higher than $5 \times 10^{-9} \mathrm{M} \mathrm{Hg}^{2+}$. The sensitivity expresses the relationship between the variation in the $\mathrm{I}_{0} / \mathrm{I}$ ratio and the logarithm of $\mathrm{Hg}^{2+}$ concentration, whose value was $0.0582 \Delta\left(\mathrm{I}_{0} / \mathrm{I}\right) / \log \left(\mathrm{Hg}^{2+}\right), \mathrm{R}^{2}=0.9850$.



Figure 5. Normalized luminescence intensity for different $\mathrm{Hg}^{2+}$ concentrations: $0 \mathrm{M}, 5 \times 10^{-12} \mathrm{M}$, $10^{-11} \mathrm{M}, 5 \times 10^{-11} \mathrm{M}, 10^{-10} \mathrm{M}, 5 \times 10^{-10} \mathrm{M}, 10^{-9} \mathrm{M}$, and $5 \times 10^{-9} \mathrm{M}$.

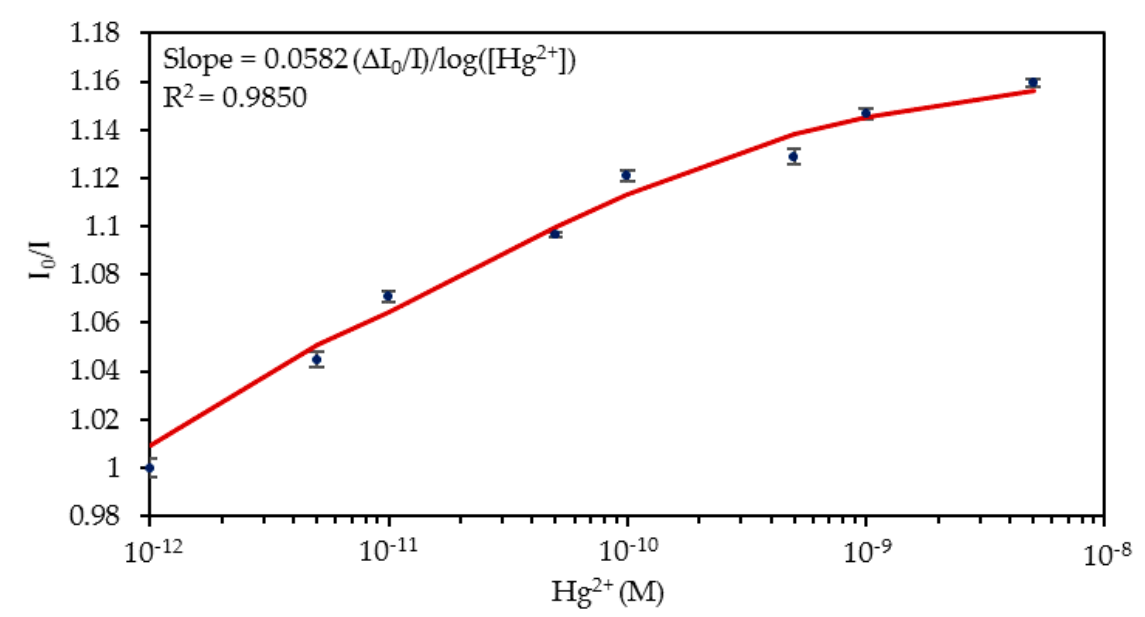

Figure 6. $\mathrm{I}_{0} / \mathrm{I}$ ratio for the different $\mathrm{Hg}^{2+}$ concentrations in PBS solution. The horizontal axis is shown in logarithmic scale. 


\subsection{Detection of $\mathrm{Hg}^{2+}$ Ions in Ultrapure Water}

In order to analyze the feasibility of using this sensor in a real application, the detection of $\mathrm{Hg}^{2+}$ ions in ultrapure water was studied. As well as in the previous case, the sensor was exposed to an increasing $\mathrm{Hg}^{2+}$ concentration series (from $5 \times 10^{-12} \mathrm{M} \mathrm{Hg}^{2+}$ to $5 \times 10^{-10} \mathrm{M} \mathrm{Hg}^{2+}$ ) in ultrapure water, regenerating the probe with a $0.5 \%(\mathrm{w} / \mathrm{w})$ SDS solution and then immersed in ultrapure water until the luminescent intensity was stabilized. The dynamic variation of the normalized luminescence is displayed in Figure $7 \mathrm{a}$ and detailed in Figure $7 \mathrm{~b}$. The resulting $\mathrm{I}_{0} / \mathrm{I}$ ratios are shown in Figure 8. As observed in the PBS solutions, the dynamic response of the sensor ranged from $5 \times 10^{-12} \mathrm{M}$ to $10^{-10} \mathrm{M} \mathrm{Hg}^{2+}$. The obtained LOD value was $9.03 \times 10^{-13} \mathrm{M} \mathrm{Hg}^{2+}$, which was slightly higher than in the case of detecting $\mathrm{Hg}^{2+}$ ions in $10 \mathrm{mM}$ PBS (pH 7.4) solution.

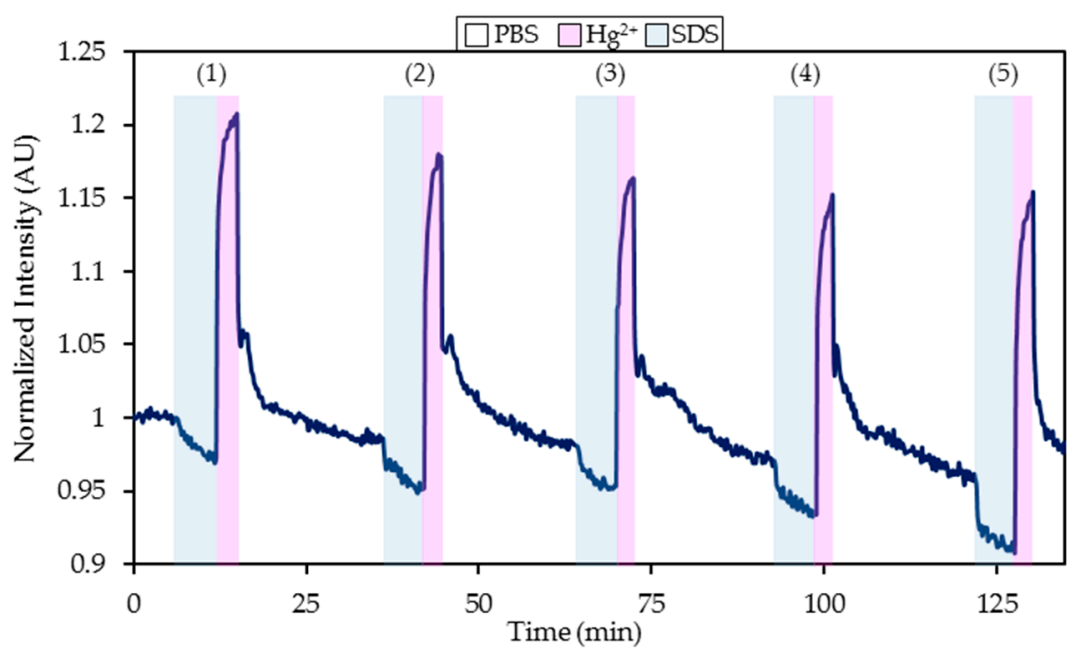

(a)

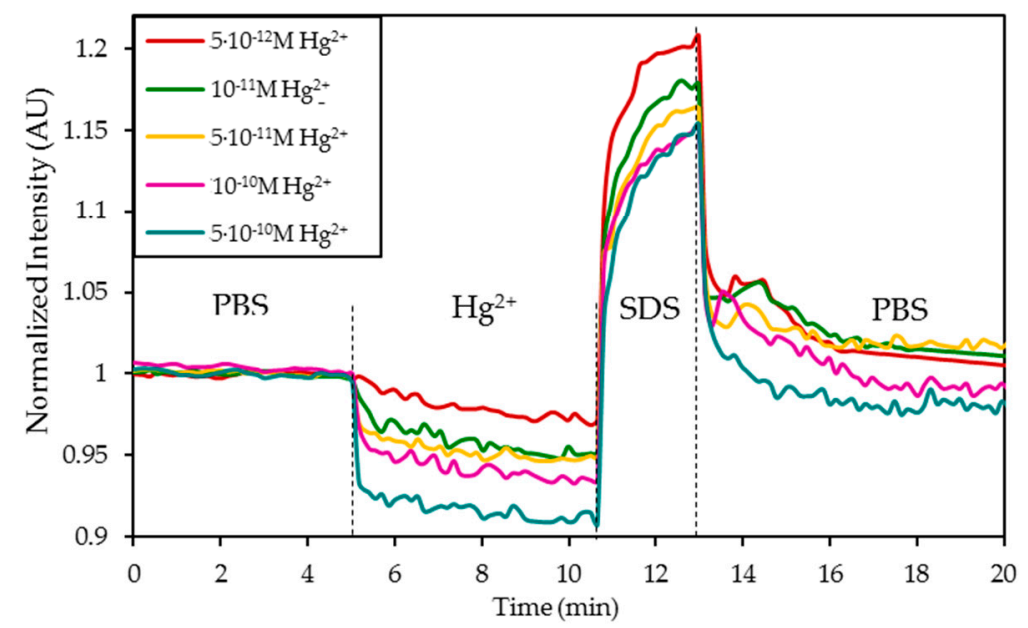

(b)

Figure 7. (a) Dynamic variation of the normalized luminescence intensity after 5 min exposure to different $\mathrm{Hg}^{2+}$ concentrations ((1) $5 \times 10^{-12} \mathrm{M}$, (2) $10^{-11} \mathrm{M}$, (3) $5 \times 10^{-11} \mathrm{M}$, (4) $10^{-10} \mathrm{M},(5) 5 \times 10^{-10} \mathrm{M}$, (6) $10^{-9} \mathrm{M}$, (7) $\left.5 \times 10^{-9} \mathrm{M}\right), 2 \mathrm{~min}$ regeneration with $0.5 \% \mathrm{w} / \mathrm{w}$ SDS and $20 \mathrm{~min}$ stabilization in ultrapure $\mathrm{H}_{2} \mathrm{O}$. (b) Detail of the intensity variation for each $\mathrm{Hg}^{2+}$ concentration in ultrapure water.

The lower sensitivity $0.0337 \Delta\left(\mathrm{I}_{0} / \mathrm{I}\right) / \log \left(\mathrm{Hg}^{2+}\right),\left(\mathrm{R}^{2}=0.9550\right)$ that the sensor presented in ultrapure water could be explained by the $\mathrm{pH}$ of the solutions: while in the previous study the $\mathrm{pH}$ value of the reference (PBS) and the $\mathrm{Hg}^{2+}$ solutions was 7.4, in this case, the $\mathrm{pH}$ values of the different solutions varied from 5.7 and 6, whereas that of the ultrapure water was 4.94 (Supplementary Table S2). First, it must be taken into account that $\mathrm{ON}$ sequences are stable in the $\mathrm{pH}$ range $7.0-8.0$ and second, that the 
$\mathrm{pH}$ value can affect the structure of the binding sequence, being maximal at $\mathrm{pH} 7.5$ and lower at different $\mathrm{pH}$ values [46,48]. Although the $\mathrm{pH}$ range of the water was not the optimum for the operation of the $\mathrm{ON}$ sequence, the sensor presented a proper and repetitive response to the different concentrations of $\mathrm{Hg}^{2+}$ ions.

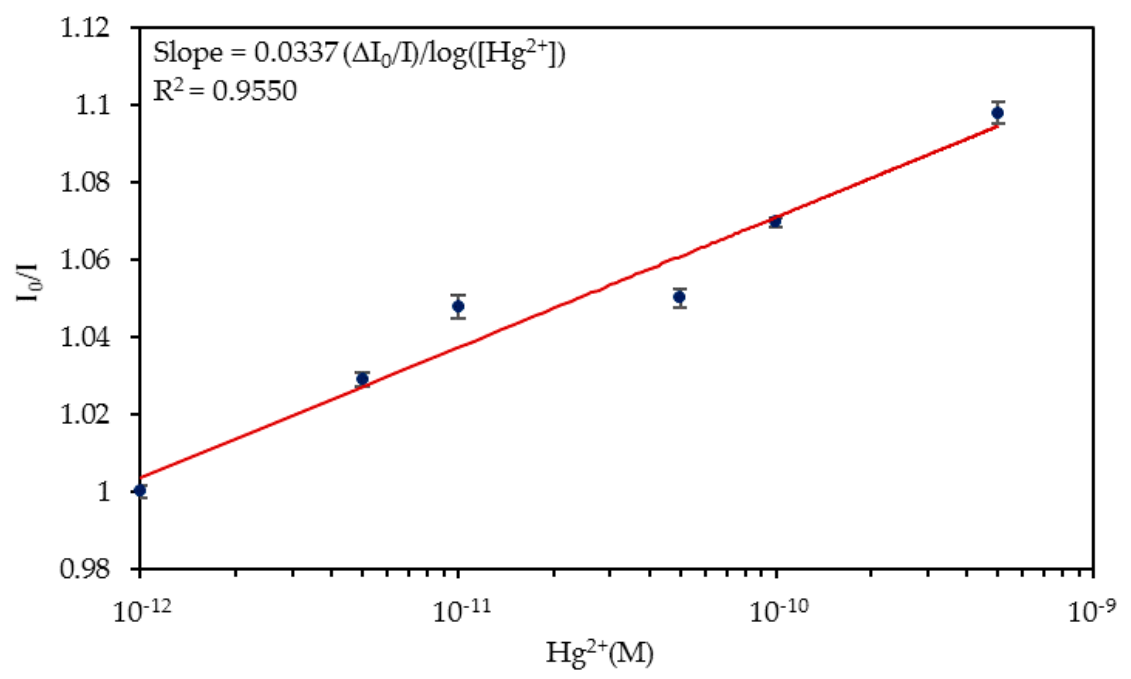

Figure 8. $\mathrm{I}_{0} / \mathrm{I}$ ratio for the different $\mathrm{Hg}^{2+}$ concentrations in ultrapure water. The horizontal axis is shown in logarithmic scale.

\subsection{Detection of $\mathrm{Hg}^{2+}$ Ions in Tap Water}

The sensor was also exposed to tap water samples spiked with different $\mathrm{Hg}^{2+}$ concentrations (from $5 \times 10^{-12} \mathrm{M} \mathrm{Hg}^{2+}$ to $5 \times 10^{-10} \mathrm{M} \mathrm{Hg}^{2+}$ ). As it did not respond to dynamic changes in the $\mathrm{Hg}^{2+}$ concentration, it was decided to investigate the possibility of utilizing these sensors as single-use probes. Different devices were exposed to the $\mathrm{Hg}^{2+}$ concentrations as previously mentioned. The $\mathrm{I}_{0} / \mathrm{I}$ ratio of each sensor exposed to a different concentration is shown in Figure 9.

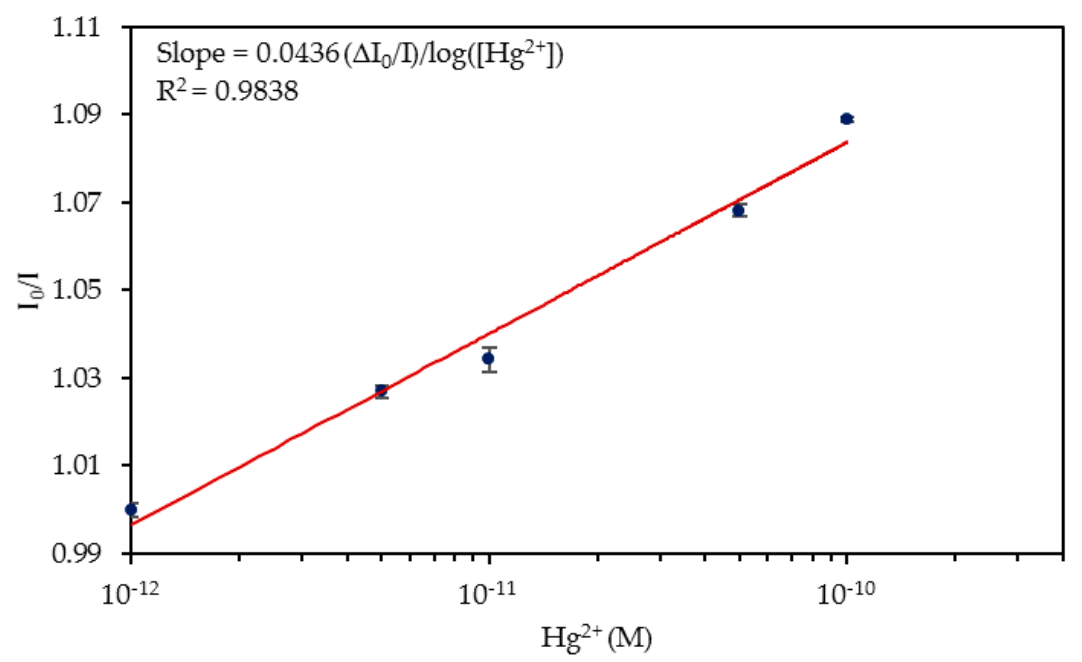

Figure 9. $\mathrm{I}_{0} / \mathrm{I}$ ratio for the different $\mathrm{Hg}^{2+}$ concentrations in tap water. The horizontal axis is shown in logarithmic scale.

In this case, the sensitivity of $0.0436 \Delta\left(\mathrm{I}_{0} / \mathrm{I}\right) / \log \left(\mathrm{Hg}^{2+}\right)\left(\mathrm{R}^{2}=0.9838\right)$ was higher than those exhibited in ultrapure water and slightly lower than the ones shown in the PBS solution. This fact could also be explained by the $\mathrm{pH}$ value of the solutions, which was 7.85 in the absence of $\mathrm{Hg}^{2+}$ ions and 7.9 in their presence (values shown in Supplementary Table S3). These $\mathrm{pH}$ values, although not being the 
optimal ones for sensing with aptamers [49], were closer than the $\mathrm{pH}$ values of the ultrapure water to that value. Table 1 shows the sensitivities obtained depending on the $\mathrm{Hg}^{2+}$ aqueous media.

Table 1. Sensitivities measured for the different aqueous solutions.

\begin{tabular}{ccc}
\hline Media & $\begin{array}{c}\text { Sensitivity } \\
\boldsymbol{\Delta}\left(\mathbf{I}_{\mathbf{0}} / \mathbf{I}\right) / \mathbf{l o g}\left(\left[\mathbf{H g}^{2+}\right]\right)\end{array}$ & $\mathbf{R}^{\mathbf{2}}$ \\
\hline PBS solutions & 0.0582 & 0.9850 \\
\hline Ultrapure water & 0.0337 & 0.9550 \\
\hline Tap Water & 0.0436 & 0.9838 \\
\hline
\end{tabular}

A possible solution for the problems above-mentioned could be the dilution of the tap water samples into a PBS buffer. This fact, which will be analyzed in further research, would avoid the effect of the $\mathrm{pH}$ value on the response of the aptamers.

\subsection{Study of the Cross-Sensitivity}

As good selectivity is a key feature for this sensor, the device was exposed to $10^{-6} \mathrm{M}$ concentrations of other metal ions $\left(\mathrm{Co}^{2+}, \mathrm{Ag}^{+}, \mathrm{Cd}^{2+}, \mathrm{Zn}^{2+}, \mathrm{Ni}^{2+}, \mathrm{Ca}^{2+}, \mathrm{Pb}^{2+}, \mathrm{Mn}^{2+}, \mathrm{Fe}^{3+}\right.$, and $\left.\mathrm{Cu}^{2+}\right)$ as well as to $10^{-9} \mathrm{M} \mathrm{Hg}^{2+}$. The results of the test are displayed in Figure 10. Although present in a concentration $10^{3}$ higher than that of $\mathrm{Hg}^{2+}$, the other metallic ions barely interacted with the sensor. While $10^{-6} \mathrm{M}$ of $\mathrm{Cd}^{2+}, \mathrm{Ni}^{2+}, \mathrm{Ca}^{2+}, \mathrm{Pb}^{2+}$, and $\mathrm{Cu}^{2+}$ induced a slight decrease in the luminescence $\left(\mathrm{I}_{0} / \mathrm{I}=1.002,1.007\right.$, $1.0004,1.005$ and 1.004, respectively), $\mathrm{Mn}^{2+}$ and $\mathrm{Zn}^{2+}$ caused a minor increment $\left(\mathrm{I}_{0} / \mathrm{I}=0.998\right.$ for $\mathrm{Mn}^{2+}$ and $\mathrm{I}_{0} / \mathrm{I}=0.998$ for $\mathrm{Zn}^{2+}$ ) in the luminescent emission. $\mathrm{Fe}^{3+}, \mathrm{Ag}^{+}$, and $\mathrm{Co}^{2+}$ were the most interfering ions: in these cases, the sensor showed $\mathrm{I}_{0} / \mathrm{I}$ values of $1.04,1.028$, and 1.034 , respectively. In each case, for an ion concentration $10^{3}$ times higher than that of $\mathrm{Hg}^{2+}$, the variation of the signal was five times lower than that induced by $10^{-9} \mathrm{M} \mathrm{Hg}^{2+}$. This result showed the low cross-sensitivity of the sensor toward other metallic ions.

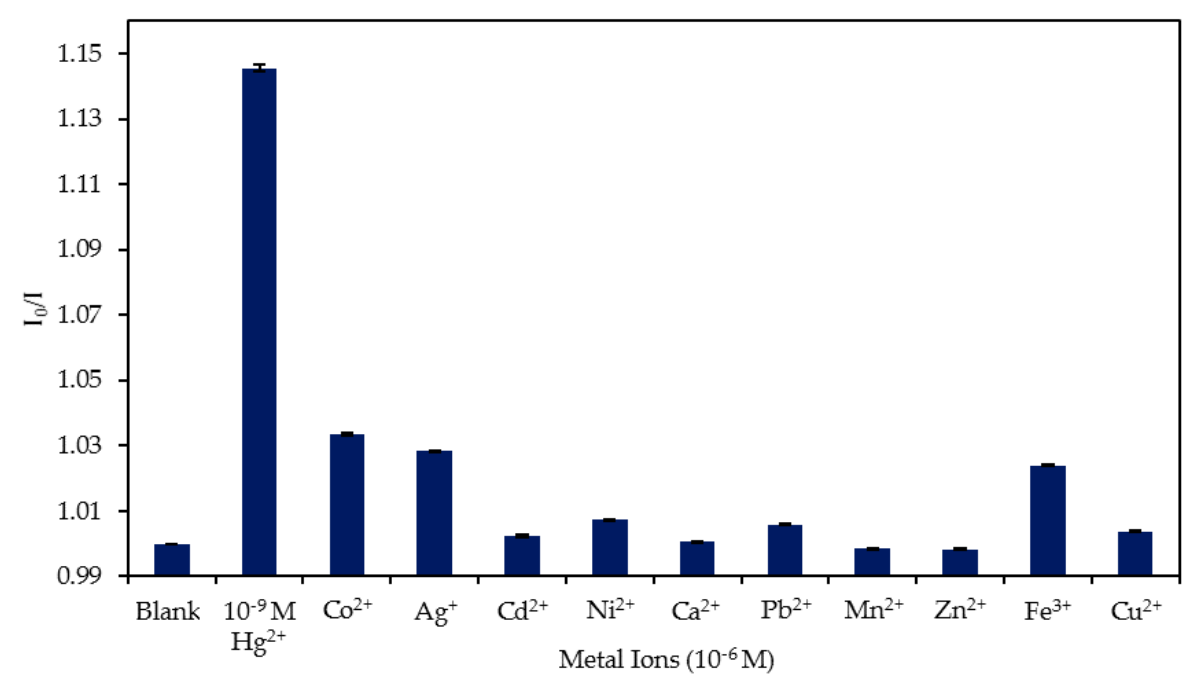

Figure 10. Comparison of the $\mathrm{I}_{0} / \mathrm{I}$ ratio of the sensor in the absence of metal ions (blank), in the presence of $10^{-9} \mathrm{M} \mathrm{Hg}^{2+}$ and in the presence of $10^{-6} \mathrm{M}$ of $\mathrm{Co}^{2+}, \mathrm{Ag}^{+}, \mathrm{Cd}^{2+}, \mathrm{Ni}^{2+}, \mathrm{Ca}^{2+}, \mathrm{Pb}^{2+}, \mathrm{Mn}^{2+}, \mathrm{Zn}^{2+}, \mathrm{Fe}^{3+}$, and $\mathrm{Cu}^{2+}$.

\section{Conclusions}

A turn-off fluorescent sensor for the detection of $\mathrm{Hg}^{2+}$ ions was fabricated with a fluorophore-labeled T-rich ON sequence, which enabled its direct immobilization onto the tapered end of an optical fiber. Furthermore, there was no need to use a fluorescence quencher or a complementary sequence as the 
$\mathrm{T}-\mathrm{Hg}^{2+}-\mathrm{T}$ mismatches formed in the presence of that metal ion attenuated the emitted luminescence. The sensor was capable of continuously monitoring dynamic variations in the $\mathrm{Hg}^{2+}$ concentration and presented a LOD of $4.73 \times 10^{-13} \mathrm{M} \mathrm{Hg}^{2+}$ in PBS buffer, moreover, the base line was recovered at values that ranged from $95.8 \%$ to $99.17 \%$. Moreover, the sensor showed an almost negligible cross-sensitivity toward other metal ions and was also able of detecting $5 \times 10^{-12} \mathrm{M} \mathrm{Hg}^{2+}$ ions in ultrapure and tap water, although the $\mathrm{pH}$ should be adjusted to physiological values. Future research lines should also analyze the effect of the ON-sequence length on the sensitivity and limit of detection of the sensor.

Supplementary Materials: The following are available online at http://www.mdpi.com/1424-8220/20/8/2372/s1, Table S1: Measurement of the $\mathrm{pH}$ values and refractive indices of the $\mathrm{Hg}^{2+}$ solutions in PBS; Table S2: Measurement of the $\mathrm{pH}$ values and refractive indices of the $\mathrm{Hg}^{2+}$ solutions in ultrapure water; Table S3: Measurement of the $\mathrm{pH}$ values and refractive indices of the $\mathrm{Hg}^{2+}$ solutions in tap water.

Author Contributions: Conceptualization and Methodology, N.D.A., C.E., and F.J.A.; Formal analysis, N.D.A.; Investigation and Validation, N.D.A., C.E., and F.J.A.; Writing-Original Draft Preparation, N.D.A.; Writing-Review \& Editing, C.E.; Supervision, C.E. and F.J.A.; Project Administration and Funding Acquisition, F.J.A. All authors have read and agreed to the published version of the manuscript.

Funding: This work was supported by the Spanish State Research Agency (AEI) and the Spanish Ministry of Economy and Competitiveness through the TEC2016-79367-C2-2-R project.

Conflicts of Interest: The authors declare no conflicts of interest.

\section{References}

1. WHO. Drinking-Water. World Health Organization Fact Sheets. 2018. Available online: https://www.who. int/en/news-room/fact-sheets/detail/drinking-water (accessed on 22 October 2019).

2. $\quad$ Eriksen, M.; Lebreton, L.C.; Carson, H.S.; Thiel, M.; Moore, C.J.; Borerro, J.C.; Galgani, F.; Ryan, P.G.; Reisser, J. Plastic Pollution in the World's Oceans: More than 5 Trillion Plastic Pieces Weighing over 250,000 Tons Afloat at Sea. PLoS ONE 2014, 9, 1-15. [CrossRef] [PubMed]

3. Blanchoud, H.; Moreau-Guigon, E.; Farrugia, F.; Chevreuil, M.; Mouchel, J.M. Contribution by urban and agricultural pesticide uses to water contamination at the scale of the Marne watershed. Sci. Total Environ. 2007, 375, 168-179. [CrossRef] [PubMed]

4. Bansod, B.; Kumar, T.; Thakur, R.; Rana, S.; Singh, I. A review on various electrochemical techniques for heavy metal ions detection with different sensing platforms. Biosens. Bioelectron. 2017, 94, 443-455. [CrossRef]

5. Dirilgen, N. Mercury and lead: Assessing the toxic effects on growth and metal accumulation by Lemna minor. Ecotoxicol. Environ. Saf. 2011, 74, 48-54. [CrossRef] [PubMed]

6. Carocci, A.; Rovito, N.; Sinicropi, M.S.; Genchi, G. Mercury toxicity and neurodegenerative effects. In Reviews of Environmental Contamination and Toxicology; Springer: Cham, Switzerland, 2014; Volume 229, pp. 1-18.

7. Jaishankar, M.; Tseten, T.; Anbalagan, N.; Mathew, B.B.; Beeregowda, K.N. Toxicity, mechanism and health effects of some heavy metals. Interdiscip. Toxicol. 2014, 7, 60-72. [CrossRef]

8. Jan, A.T.; Azam, M.; Siddiqui, K.; Ali, A.; Choi, I.; Haq, Q.M.R. Heavy metals and human health: Mechanistic insight into toxicity and counter defense system of antioxidants. Int. J. Mol. Sci. 2015, 16, 29592-29630. [CrossRef]

9. C. of the E. U. European Parliament. Directive 2013/39/EU of the European Parliament and of the Council of 12 August 2013 amending Directives 2000/60/EC and 2008/15/EC as Regards Priority Substances in the Field of Water Policy Text with EEA relevance. Available online: https://eur-lex.europa.eu/LexUriServ/LexUriServ. do?uri=OJ:L:2008:348:0084:0097:EN:PDF (accessed on 20 February 2020).

10. Liu, C.; Chen, X.; Zong, B.; Mao, S. Recent advances in sensitive and rapid mercury determination with graphene-based sensors. J. Mater. Chem. A 2019, 7, 6616-6630. [CrossRef]

11. Chen, G.; Guo, Z.; Zeng, G.; Tang, L. Fluorescent and colorimetric sensors for environmental mercury detection. Analyst 2015, 140, 5400-5443. [CrossRef]

12. Pokhrel, L.R. Novel carbon nanotube (CNT)-based ultrasensitive sensors for trace mercury (II) detection in water: A review. Sci. Total Environ. 2017, 574, 1379-1388. [CrossRef]

13. National Research Council. Chapter 6: Chemical Sensors. In Expanding the Vision of Sensor Materials; National Academies Press: Washington, DC, USA, 1995. 
14. Lakhin, A.V.; Tarantul, V.Z.; Gening, L.V. Aptamers: Problems, solutions and prospects. Acta Nat. 2013, 5, 34-43. [CrossRef]

15. Miyake, Y. Mercury ${ }^{\mathrm{II}}$-mediated formation of thymine-Hg ${ }^{\mathrm{II}}$-thymine base pairs in DNA duplexes. J. Am. Chem. Soc. 2006, 128, 2172-2173. [CrossRef] [PubMed]

16. Daniel, S.C.G.K.; Kumar, A.; Sivasakthi, K.; Thakur, C.S. Handheld, low-cost electronic device for rapid, real-time fluorescence-based detection of $\mathrm{Hg}^{2+}$, using aptamer-templated $\mathrm{ZnO}$ quantum dots. Sens. Actuators B Chem. 2019, 290, 73-78. [CrossRef]

17. Li, M.; Zhou, X.; Ding, W.; Guo, S.; Wu, N. Fluorescent aptamer-functionalized graphene oxide biosensor for label-free detection of mercury(II). Biosens. Bioelectron. 2013, 41, 889-893. [CrossRef]

18. De Acha, N.; Elosúa, C.; Corres, J.M.; Arregui, F.J. Fluorescent sensors for the detection of heavy metal ions in aqueous media. Sensors 2019, 19, 599. [CrossRef]

19. Guo, L.; Yin, N.; Chen, G. Photoinduced electron transfer mediated by $\pi$-stacked thymine-Hg ${ }^{2+}$-thymine base pairs. J. Phys. Chem. C 2011, 115, 4837-4842. [CrossRef]

20. Freeman, R.; Finder, T.; Willner, I. Multiplexed analysis of $\mathrm{Hg}^{2+}$ and $\mathrm{Ag}^{+}$ions by nucleic acid functionalized CdSe/ZnS quantum dots and their use for logic gate operations. Angew. Chemie-Int. Ed. 2009, 48, 7818-7821. [CrossRef]

21. Zhang, J.; Huang, Y.; Yan, J.; Zhu, C.; Zhang, C.; Chen, A. Dulplex analysis of mercury and silver ions using a label-free fluorescent aptasensor. Int. J. Environ. Anal. Chem. 2018, 98, 349-359. [CrossRef]

22. Liu, C.-W.; Huang, C.-C.; Chang, H.-T. Highly selective DNA-based sensor for lead (II) and mercury (II) ions. Anal. Chem. 2009, 81, 2383-2387. [CrossRef]

23. López-Higuera, J.M.; Cobo, L.R.; Incera, A.Q.; Cobo, A. Fiber optic sensors in structural health monitoring. J. Light. Technol. 2011, 29, 587-608. [CrossRef]

24. Park, H.J.; Yoon, J.H.; Lee, K.G.; Choi, B.G. Potentiometric performance of flexible pH sensor based on polyaniline nanofiber arrays. Nano Converg. 2019, 6, 9. [CrossRef]

25. Zhang, Z. High-Sensitivity Gas-Pressure Sensor Based on Fiber-Tip PVC Diaphragm Fabry-Pérot Interferometer. J. Light. Technol. 2017, 35, 4067-4071. [CrossRef]

26. Yang, J.; Che, X.; Shen, R.; Wang, C.; Li, X.; Chen, W. High-sensitivity photonic crystal fiber long-period grating methane sensor with cryptophane-A-6Me absorbed on a PAA-CNTs/PAH nanofilm. Opt. Express 2017, 25, 20258-20267. [CrossRef]

27. Zubiate, P. Fiber-based early diagnosis of venous thromboembolic disease by label-free D-dimer detection. Biosens. Bioelectron. X 2019, 2, 100026. [CrossRef]

28. Rivero, P.J.; Goicoechea, J.; Arregui, F.J. Layer-by-layer nano-assembly: A powerful tool for optical fiber sensing applications. Sensors 2019, 19, 683. [CrossRef] [PubMed]

29. De Acha, N.; Elosúa, C.; Matías, I.R.; Arregui, F.J. Enhancement of luminescence-based optical fiber oxygen sensors by tuning the distance between fluorophore layers. Sens. Actuators B Chem. 2017, 248, 836-847. [CrossRef]

30. Jorge, P.A.S.; Caldas, P.; Rosa, C.C.; Oliva, A.G.; Santos, J.L. Optical fiber probes for fluorescence based oxygen sensing. Sens. Actuators B Chem. 2004, 103, 290-299. [CrossRef]

31. Li, Z.; Muhandiramlage, T.P.; Keogh, J.P.; Hall, H.K.; Aspinwall, C.A. Aptamer-functionalized porous phospholipid nanoshells for direct measurement of $\mathrm{Hg}^{2+}$ in urine. Anal. Bioanal. Chem. 2015, 407, 953-960. [CrossRef]

32. Long, F.; Zhu, A.; Wang, H. Optofluidics-based DNA structure-competitive aptasensor for rapid on-site detection of lead(II) in an aquatic environment. Anal. Chim. Acta 2014, 849, 43-49. [CrossRef]

33. Anderson, G.P.; Golden, J.P.; Ligler, F.S. A fiber optic biosensor: Combination tapered fibers designed for improved signal acquisition. Biosens. Bioelectron. 1993, 8, 249-256. [CrossRef]

34. Golden, J.P.; Anderson, G.P.; Rabbany, S.Y.; Ligler, F.S. An Evanescent Wave Biosensor-Part II: Fluorescent Signal Acquisition from Tapered Fiber Optic Probes. IEEE Trans. Biomed. Eng. 1994, 41, 585-591. [CrossRef]

35. Long, F. Reusable evanescent wave DNA biosensor for rapid, highly sensitive, and selective detection of mercury ions. Biosens. Bioelectron. 2011, 26, 4018-4023. [CrossRef] [PubMed]

36. Hasegawa, H.; Taira, K.-I.; Sode, K.; Ikebukuro, K. Improvement of aptamer affinity by dimerization. Sensors 2008, 8, 1090-1098. [CrossRef] [PubMed]

37. Ono, A.; Togashi, H. Highly selective oligonucleotide-based sensor for mercury (II) in aqueous solutions. Angew. Chemie Int. Ed. 2004, 43, 4300-4302. [CrossRef] 
38. Ono, A. Development of novel oligonucleotide-based sensors which are highly $\mathrm{Hg}$ (II) selective and are insensitive to other heavy metal ions. Nucleic Acids Symp. Ser. (Oxf). 2004, 48, 29-30. [CrossRef]

39. Zeng, X.; Zhang, F.S.; Zhu, B.; Zhu, L. Fluorescence Determination of Merucury (II) Using a Thymine Aptamer. Anal. Lett. 2015, 48, 2208-2216. [CrossRef]

40. Mattos, A.B.; Freitas, T.A.; Silva, V.L.; Dutra, R.F. A dual quartz crystal microbalance for human cardiac troponin T in real time detection. Sens. Actuators B Chem. 2012, 161, 439-446. [CrossRef]

41. Elosua, C.; de Acha, N.; Hernaez, M.; Matias, I.R.; Arregui, F.J. Layer-by-Layer assembly of a water-insoluble platinum complex for optical fiber oxygen sensors. Sens. Actuators B Chem. 2015, 207, 683-689. [CrossRef]

42. Li, J. A 'turn-off' fluorescent biosensor for the detection of mercury (II) based on graphite carbon nitride. Talanta 2017, 162, 46-51. [CrossRef]

43. Sung, T.-W.; Lo, Y.-L. Dual sensing of temperature and oxygen using PtTFPP-doped CdSe/SiO ${ }_{2}$ core-shell nanoparticles. Sens. Actuators B Chem. 2012, 173, 406-413. [CrossRef]

44. Wenzel, M.J.; Mensah-Brown, A.; Josse, F.; Yaz, E.E. Online drift compensation for chemical sensors using estimation theory. IEEE Sens. J. 2011, 11, 225-232. [CrossRef]

45. Bhuyan, A.K. On the mechanism of SDS-induced protein denaturation. Biopolymers 2010, 93, $186-199$. [CrossRef] [PubMed]

46. Lin, Y.-W.; Liu, C.-W.; Chang, H.-T. Fluorescence detection of mercury (II) and lead (II) ions using aptamer/reporter conjugates. Talanta 2011, 84, 324-329. [CrossRef] [PubMed]

47. Shrivastava, A.; Gupta, V.B. Methods for the determination of limit of detection and limit of quantification of the analytical methods. Chron. Young Sci. 2011, 2, 21-25. [CrossRef]

48. Huang, P.-J.J.; Kempaiah, R.; Liu, J. Synergistic pH effect for reversible shuttling aptamer-based biosensors between graphene oxide and target molecules. J. Mater. Chem. 2011, 21, 8991-8993. [CrossRef]

49. Hianik, T.; Ostatná, V.; Sonlajtnerova, M.; Grman, I. Influence of ionic strength, pH and aptamer configuration for binding affinity to thrombin. Bioelectrochemistry 2007, 70, 127-133. [CrossRef]

(C) 2020 by the authors. Licensee MDPI, Basel, Switzerland. This article is an open access article distributed under the terms and conditions of the Creative Commons Attribution (CC BY) license (http://creativecommons.org/licenses/by/4.0/). 